\title{
Solid State Deproteinization of Shrimp Shells by Aspergillus niger with Galactose as a Bioavailable Carbon Supplement
}

\author{
Abdel Ghaly ${ }^{1 *}$ and Nesreen Mahmoud ${ }^{2}$ \\ ${ }^{1}$ Department of Process Engineering and Applied Science, Faculty of Engineering, Dalhousie University, Halifax, Nova Scotia, Canada \\ ${ }^{2}$ Department of Agricultural Engineering, Faculty of Agriculture, Cairo University, Giza, Egypt
}

\begin{abstract}
The aim of the research was to evaluate the ability of the fungus Aspergillus niger to produce protease and carry out the deproteinization of shrimp shells and study the effect of adding galactose as an external carbon source at three concentrations $(10,20$ and $30 \% \mathrm{w} / \mathrm{w})$ on the performance of the deproteinization process. The results showed that the $20 \%$ galactose concentration was optimum whereas the $10 \%$ galactose concentration did not support enough microbial growth and the $30 \%$ galactose concentration inhibited the growth of $A$. niger as was evident from the temperature and carbon dioxide evolution profiles. The temperatures of the shrimp shells and exhaust gas decreased in the first 12 hours (lag) because the heat losses due to evaporation of water (latent heat) and the cooling effect of the inlet air were higher than the heat generation by microorganisms. It then increased as a result of heat accumulation in the bioreactor reaching 28.9- 38.3 and $24.9-29.0^{\circ} \mathrm{C}$, respectively. There was a strong correlation between the concentrations of carbon dioxide in the exhaust gas and the temperature of the shrimp shells. Although the inlet air was humidified, a significant reduction in the moisture content (from $60 \%$ to $25.20-43.71 \%$ ) was noticed by the end of the deproteinization process because the moisture lost through evaporation exceeded the metabolic water production. The $\mathrm{pH}$ of the shrimp shells decreased with time to 5.92-6.63 due to acid protease production and then increased to $6.28-8.32$ due to the buffering capacity of the calcium carbonate released from the shrimp shells. The protease activity increased from $0.71 \mathrm{U} / \mathrm{g}$ to $1.77-1.85 \mathrm{U} / \mathrm{g}$ whereas the protein concentration in the shrimp shells decreased from $30.84 \%$ to $20.77-25.30 \%$ as a result of protein break down by the proteolytic enzymes produced by $A$. niger. The chitin concentration in the shrimp shells increased from $16.59 \%$ to $20.42-21.99 \%$ as a result of protein removal. The highest protease activities, protein removal efficiency and chitin concentration were achieved with galactose concentration of $20 \%$. The spent shrimp shells from the runs that received 10 and $20 \%$ galactose concentration had a pale pink-orange color. The existence of the pink-orange color was an indication of the presence of pigments which were not utilized during the fermentation process. The run that received $30 \%$ galactose concentration had a gray-black color due to the presence of $A$. niger spores. The high initial galactose concentration enhanced sporulation of the fungus.
\end{abstract}

Keywords: Shrimp shells; Protein; Chitin; Minerals; Deproteinization; Aspergillus niger; Proteases; Galactose; Temperature; pH; Moisture content

\section{Introduction}

Each year, the shellfish processing industry generates large amounts of solid wastes, which have become a major environmental concern because of their bulky nature and high perishability. Shellfish waste is a rich source of many valuable products including: chitin, protein, pigments and flavor compounds [1]. Chitin and its derivatives are versatile environmentally friendly modern materials that have been used in virtually every segment of the economy (water treatment, pulp and paper, biomedical devices and therapies, cosmetics, biotechnology, agriculture, food science, and membrane technology) because of their wide range of properties [2].

The traditional method of chitin extraction from crustacean waste involves the use of a strong acid $(\mathrm{HCl})$ for demineralization and a strong alkali $(\mathrm{NaOH})$ for deproteinization $[2,3]$. This chemical extraction has several disadvantages including: (a) yielding a chitin with variable and inconsistent physiochemical properties, (b) resulting in an effluent wastewater that creates disposal and environmental problems, (c) wasting other valuable components (protein, lipids, pigments and minerals) present in the waste material and (d) very high cost. Therefore, a less expensive and environmentally friendly method for chitin extraction is needed.

Proteolytic enzymes can be used for deproteinization of shrimp shells, either by using proteolytic microorganisms [4] or the purified proteolytic enzymes [5]. However, the use of living microbes is more effective than the purified enzymes because for two reasons: (a) the presence of microorganisms provides a constant and gradual production of protease throughout the fermentation period and (b) the microorganisms can grow in the interstices of shell waste structure which allows for closer contact between the enzyme producing site and the protein substrate $[3,4]$.

Aspergillus niger is an important microorganism that has been used in different industrial applications including production of organic acids and extracellular enzymes [6-8]. A. niger contains up to $42.0 \%$ chitin of the dry weight of the fungal cell wall which is about $20-40 \%$ of the dry cell weight [4]. Therefore, A. niger has a great potential for biological deproteinization of shrimp shells as the proteolytic enzymes released by the fungi can hydrolyze the protein in the shrimp shells and the chitin in their cell wall can be considered an additional source of chitin.

\section{Objectives}

The aim of the research was to evaluate the ability of the fungus Aspergillus niger to produce protease and carry out the deproteinization

*Corresponding author: Abdel Ghaly, Department of Process Engineering and Applied Science, Faculty of Engineering, Dalhousie University, Halifax, Nova Scotia, Canada, Tel: 902494-6014; E-mail: abdel.ghaly@dal.ca

Received April 11, 2015; Accepted May 13, 2015; Published May 20, 2015

Citation: Ghaly A, Mahmoud N (2015) Solid State Deproteinization of Shrimp Shells by Aspergillus niger with Galactose as a Bioavailable Carbon Supplement. J Bioprocess Biotech 5: 225 doi:10.4172/2155-9821.1000225

Copyright: () 2015 Ghaly A and Mahmoud N. This is an open-access article distributed under the terms of the Creative Commons Attribution License, which permits unrestricted use, distribution, and reproduction in any medium, provided the original author and source are credited. 
of shrimp shells in the presence of galactose as a readily bioavailable carbon source and study the effect of initial galactose concentration $(10,20$ and $30 \% \mathrm{w} / \mathrm{w})$ on the performance characteristics of the deproteinization process.

\section{Materials and Methods}

\section{Experimental Apparatus}

The experimental setup (Figure 1) consisted of a main frame, three drum bioreactors, an aeration system and a data acquisition system.

The main frame was made of two polyvinyl chloride (PVC) rectangular sheets (13 $\mathrm{mm}$ thick) and two hexagon stainless steel sheets ( $3 \mathrm{~mm}$ thick). One of the PVC sheets $(560 \times 460 \mathrm{~mm})$ was used as a base and the other one $(560 \times 380 \mathrm{~mm})$ was fixed vertically on the base. The two hexagon stainless steel sheets were fixed to the two PVC sheets by means of stainless steel screws. The main frame held the drum bioreactors, the pressure regulator, the flow meters, the inlet air and exhaust gas manifold, tubing and sampling ports, the thermocouple wires, the mixing motor along with the transmission system and the switch.

Three $1.8 \mathrm{~L}$ drum bioreactors with mixing motors and transmission system were used. Each drum bioreactor (Figure 2) consisted of a removable inner stainless steel mesh (aperture of $1.5 \mathrm{~mm}$ ) which was used as a lining for an outer stainless steel horizontally rotating basket of $88 \mathrm{~mm}$ diameter and $292 \mathrm{~mm}$ length. One stainless steel plate, with a drilled hole for sampling, was used to close one end of the rotating basket. The other end was left opened for charging and cleaning purposes and was designed so that it can be recessed and secured into a rotating disc after charging the reactor. An outer casing made from a Plexiglas cylinder of $12.5 \mathrm{~mm}$ diameter was installed for each bioreactor. The Plexiglas cylinder was recessed and secured into the main frame from one end by six stainless steel screws. The other end of the Plexiglas cylinder was covered by a removable circular Plexiglas plate and was recessed and secured by six stainless steel screws and wing nuts. A rubber gasket lining (O-ring, $2.5 \mathrm{~mm}$ thick) was used at both ends of the Plexiglas cylinder to provide an air tight seal. A hole was drilled through the cylinder wall for the release of the exhaust gas. The rotating discs were connected to a motor (Synchronous Motor, 20-34245G-24007, Sigma Instruments Inc., Braintree, Massachusetts., USA) through a transmission system.

Air was supplied continuously at the required flow rate inside each drum bioreactor from the laboratory air supply. The air passed first through a pressure regulator (ARO, Model no. 129125-510, Bryan, Ohio, USA) in order to regulate the air pressure around $5 \mathrm{kPa}$ and then through a 1-L humidifier which contained $0.75 \mathrm{~L}$ sterilized distilled water kept at room temperature. The humidified air was passed through a bacterial filter and then through a flow meter (No. 60648, Cole-Parmer Instrument, Chicago, Illinois, USA) and finally introduced into the bioreactor through a small perforated stainless steel tube that ran along the center of the basket. The aeration tube was fixed through the center of the rotating disc and remains stationary while the basket is rotating. The air inlet sampling port was placed right after the bacterial filter whereas the three exhaust gas sampling ports were located on the exhaust tubes; each was made of a rubber septum. The three exhaust gas tubes were connected to a manifold and the exhaust gas was bubbled through a small container of water in order to create a slight gas pressure in the bioreactors.

Eleven T-type thermocouples (Thermo Electric Ltd., Brampton, Ontario, Canada) were used to measure the temperature during the course of the fermentation process. Two thermocouples were threaded through the aeration tube of each bioreactor and used to measure the temperature of the material inside the bioreactor. The other five thermocouples were used to measure the ambient temperature (one), inlet air temperature (one) and exhaust gas temperature of each bioreactor (three). The temperature data were monitored and stored using a data acquisition system which consisted of a master unit (Multiscan 1200, Omega, Stamford, Connecticut, USA), a thermocouple/volt scanning card (MTC/24, Omega, Stamford, Connecticut, USA), a software (Tempview, Omega, Stamford, Connecticut, USA) and a personal computer.

\section{Microorganisms}

Aspergillus niger (ATCC 16513) was obtained from the American Type Culture Collection (Rockville, Maryland, USA). The freeze dried culture was revived in $6 \mathrm{ml}$ of $0.1 \%$ sterilized peptone solution,

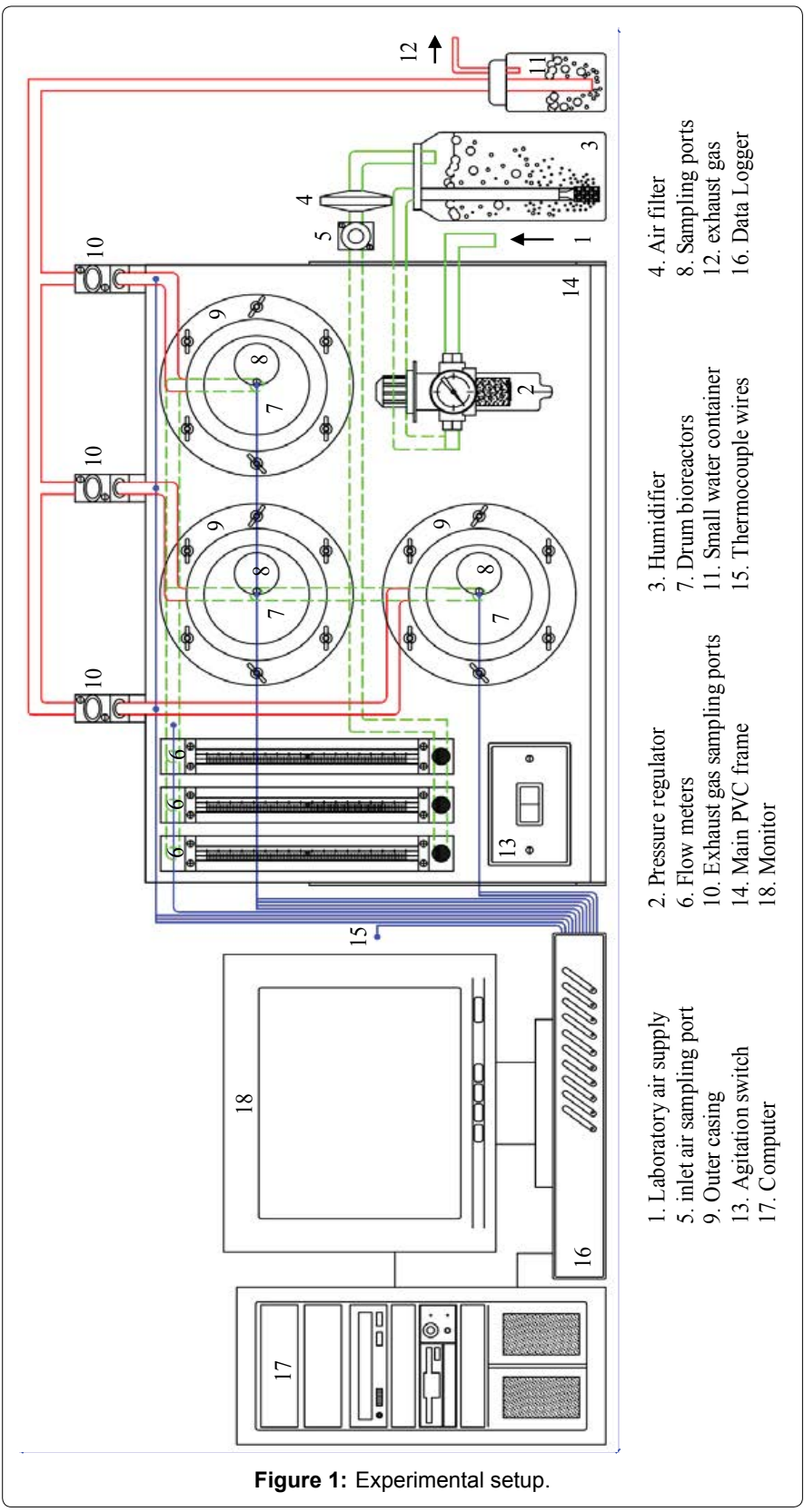


Citation: Ghaly A, Mahmoud N (2015) Solid State Deproteinization of Shrimp Shells by Aspergillus niger with Galactose as a Bioavailable Carbon Supplement. J Bioprocess Biotech 5: 225 doi:10.4172/2155-9821.1000225

Page 3 of 11
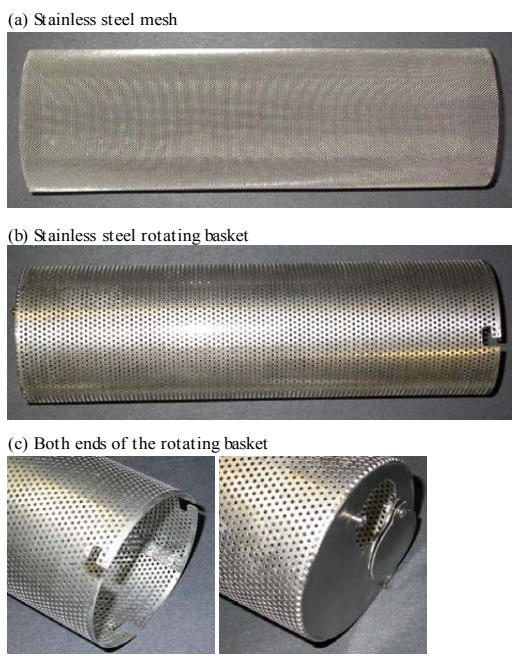

(d) Plexiglas cylinder

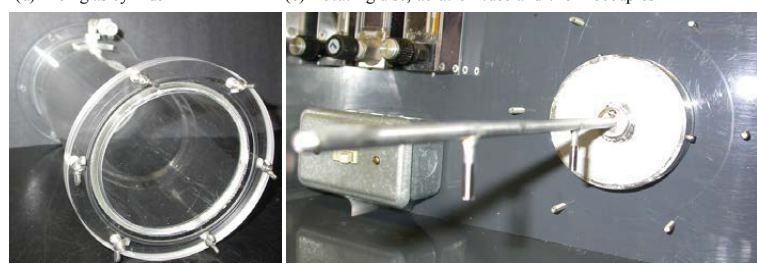

Figure 2: The drum bioreactor.

which was prepared by dissolving $1 \mathrm{~g}$ Bacto-peptone (Difco, Detroit, Michigan, USA) in $1 \mathrm{~L}$ deionized-distilled water and then sterilized in an autoclave (Model No. STM-E, Market Forge Sterilmatic, New York, USA) at $121^{\circ} \mathrm{C}$ and $103.4 \mathrm{kPa}$ for 30 minutes. The rehydrated culture was kept in the peptone solution in a capped test tube for 24 hours at room temperature $\left(21^{\circ} \mathrm{C}\right)$. One $\mathrm{ml}$ of the rehydrated $A$. niger was transferred to each of three test tubes containing $9 \mathrm{ml}$ potato dextrose broth (PDB), which contained infusion from $200 \mathrm{~g}$ potatoes $(4 \mathrm{~g} / \mathrm{L})$ and $20 \mathrm{~g} / \mathrm{L}$ Bacto dextrose. The test tubes were kept tightly capped for $48 \mathrm{~h}$ at room temperature $\left(24^{\circ} \mathrm{C}\right)$ and then stored in the fridge at $4^{\circ} \mathrm{C}$ and cultured when needed.

A spore stock suspension was obtained by growing the fungus on Czapek's agar, (which contained $30.00 \mathrm{~g} / \mathrm{L}$ saccharose, $2.00 \mathrm{~g} / \mathrm{L}$ sodium nitrate, $1.00 \mathrm{~g} / \mathrm{L}$ dipotassium phosphate, $0.50 \mathrm{~g} / \mathrm{L}$ magnesium sulfate, $0.50 \mathrm{~g} / \mathrm{L}$ potassium chloride, $0.01 \mathrm{~g} / \mathrm{L}$ ferrous sulfate and 15.00 $\mathrm{g} / \mathrm{L}$ agar) at room temperature $\left(21^{\circ} \mathrm{C}\right)$ for 4 days. The conidia were harvested from the surface by adding sterilized deionized distilled water containing $0.01 \%(\mathrm{v} / \mathrm{v})$ Tween 80 and gently scraping the surface with a sterile spatula. Tween 80 was prepared by dissolving $0.1 \mathrm{ml}$ Tween 80 in $1 \mathrm{~L}$ distilled deionized water and then autoclaving (Model No. STM-E, Market Forge Sterilmatic, New York, USA) at $121^{\circ} \mathrm{C}$ and $103.4 \mathrm{kPa}$ for 30 minutes. The spore concentration was determined using direct standard plate count method according to the procedures described in the Standard Method for the Examination of Dairy Products [9]. The prepared suspension was stored in the refrigerator at about $4^{\circ} \mathrm{C}$ until needed.

\section{Shrimp shells}

The shells of the Northern Pink Shrimp (Pandalus borealis) were obtained from a shell processing plant in Mulgrave, owned by Ocean Nutrition Ltd. of Bedford, Nova Scotia. Pandalus borealis is commonly fished in the North Atlantic East Coast of Canada and has a mean length of 22-25 $\mathrm{mm}$ at maturity [10]. The shrimp shells were stored at about $-25^{\circ} \mathrm{C}$ in the Biotechnology Laboratory of Dalhousie University in Halifax till needed. The shrimp shells were autoclaved (Model No. STM-E, Market Forge Sterilmatic, New York, USA) at $121^{\circ} \mathrm{C}$ and 103.4 $\mathrm{kPa}$ for $45 \mathrm{~min}$ before use. Table 1 shows some of the characteristics of the shrimp shells. Table 2 show the particle size distribution of the shrimp shells.

\section{Experimental protocol}

The experimental conditions for the deproteinization process are shown in Table 3. The effect of three initial galactose concentrations $(10,20$ and $30 \% \mathrm{w} / \mathrm{w})$ on the deprotenization process of shrimp shells

\begin{tabular}{|c|c|c|}
\hline Characteristics & Value & Units \\
\hline Moisture content & $4.79 \pm 0.03$ & $\%$ \\
\hline Ash content & $31.73 \pm 0.02$ & $\%$ \\
\hline Total Kjeldahl nitrogen & 64265 & $\mathrm{mg} / \mathrm{kg}$ \\
\hline Ammonium nitrogen ${ }^{\mathrm{a}}$ & 3492 & $\mathrm{mg} / \mathrm{kg}$ \\
\hline Percent ammonium nitrogen ${ }^{a}$ & 5.4 & $\%$ \\
\hline Organic nitrogen ${ }^{a}$ & 60773 & $\mathrm{mg} / \mathrm{kg}$ \\
\hline Percent organic nitrogen ${ }^{a}$ & 94.6 & $\%$ \\
\hline Protein nitrogen ${ }^{a}$ & 49339 & $\mathrm{mg} / \mathrm{kg}$ \\
\hline Percent protein nitrogen ${ }^{a}$ & 76.8 & $\%$ \\
\hline Chitin nitrogen $^{a}$ & 11434 & $\mathrm{mg} / \mathrm{kg}$ \\
\hline Percent chitin nitrogen $^{a}$ & 17.8 & $\%$ \\
\hline Chitin $^{b}$ & 165907 & $\mathrm{mg} / \mathrm{kg}$ \\
\hline Protein $^{c}$ & 308369 & $\mathrm{mg} / \mathrm{kg}$ \\
\hline Fat & 22000 & $\mathrm{mg} / \mathrm{kg}$ \\
\hline Total carbon & 305000 & $\mathrm{mg} / \mathrm{kg}$ \\
\hline Total organic carbon & 176000 & $\mathrm{mg} / \mathrm{kg}$ \\
\hline \multicolumn{3}{|l|}{ Elements } \\
\hline Magnesium $^{a}$ & 6150 & $\mathrm{mg} / \mathrm{kg}$ \\
\hline Calcium $^{a}$ & 142000 & $\mathrm{mg} / \mathrm{kg}$ \\
\hline Manganese $^{a}$ & 116 & $\mathrm{mg} / \mathrm{kg}$ \\
\hline Potassium $^{\mathrm{a}}$ & 871 & $\mathrm{mg} / \mathrm{kg}$ \\
\hline Sodium $^{\mathrm{a}}$ & 3480 & $\mathrm{mg} / \mathrm{kg}$ \\
\hline Iron $^{\mathrm{a}}$ & 308 & $\mathrm{mg} / \mathrm{kg}$ \\
\hline Phosphorus $^{a}$ & 22400 & $\mathrm{mg} / \mathrm{kg}$ \\
\hline Sulfura & 4700 & $\mathrm{mg} / \mathrm{kg}$ \\
\hline Silicon $^{a}$ & 794 & $\mathrm{mg} / \mathrm{kg}$ \\
\hline Aluminum ${ }^{a}$ & 250 & $\mathrm{mg} / \mathrm{kg}$ \\
\hline Copper $^{a}$ & 24 & $\mathrm{mg} / \mathrm{kg}$ \\
\hline Others $^{a}$ & 136207 & $\mathrm{mg} / \mathrm{kg}$ \\
\hline $\mathrm{pH}$ & 8.64 & \\
\hline
\end{tabular}

${ }^{\mathrm{a} C h a r a c t e r i s t i c s}$ are presented on dry basis

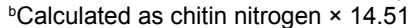

${ }^{\circ}$ Calculated as protein nitrogen $\times 6.25$

Table 1: Some characteristics ${ }^{a}$ of shrimp shells.

\begin{tabular}{|c|c|c|}
\hline $\begin{array}{c}\text { Size } \\
(\mathbf{m m})\end{array}$ & $\begin{array}{c}\text { Under } \\
\mathbf{( \% )}\end{array}$ & $\begin{array}{c}\text { Above } \\
\mathbf{( \% )}\end{array}$ \\
\hline 6.300 & 98.11 & 1.89 \\
\hline 4.000 & 88.97 & 9.13 \\
\hline 2.000 & 59.33 & 29.67 \\
\hline 0.850 & 35.74 & 64.23 \\
\hline 0.300 & 11.25 & 90.75 \\
\hline 0.180 & 3.96 & 96.04 \\
\hline 0.075 & 0.92 & 99.08 \\
\hline$<0.075$ & 0.24 & 99.78 \\
\hline
\end{tabular}

Table 2: Particle size distribution of the shrimp shells. 


\begin{tabular}{|l|l|}
\hline Parameters & Value \\
\hline Studied Parameter & Initial Galactose Concentration \\
\hline Load & $75 \%$ of the Bioreactor Volume \\
\hline Initial Moisture Content & $60 \%$ \\
\hline Inoculum Size & $1 \times 10^{7}$ Spores/g Shell \\
\hline Aeration & $5 \mathrm{VMM}$ \\
\hline Agitation & Intermittent $(15 \mathrm{~min} / \mathrm{h})$ \\
\hline Particle Size & Intact Shrimp Shells $(0.075-6.30 \mathrm{~mm})$ \\
\hline Autoclaving & Autoclaved Shrimp Shells \\
\hline Initial Galactose Concentration & 10,20 and $30 \% \mathrm{w} / \mathrm{w}$ \\
\hline Initial pH & 8.64 \\
\hline
\end{tabular}

Table 3: Experimental conditions.

\begin{tabular}{|l|l|l|l|}
\hline \multirow{2}{*}{ Parameter } & \multicolumn{3}{|l|}{ Initial galactose concentration (\% w/w) } \\
\cline { 2 - 4 } & $\mathbf{1 0}$ & $\mathbf{2 0}$ & $\mathbf{3 0}$ \\
\hline Lag phase $(\mathrm{h})$ & 12 & 12 & 12 \\
\hline Exponential phase $(\mathrm{h})$ & 60 & 60 & 96 \\
\hline Specific growth rate $\left(\mathrm{h}^{-1}\right)$ & 0.0042 & 0.0089 & 0.0058 \\
\hline Stationary phase $(\mathrm{h})$ & 2 & 5 & 11 \\
\hline Initial temperature $\left({ }^{\circ} \mathrm{C}\right)$ & 21.8 & 21.8 & 21.8 \\
\hline Maximum temperature $\left({ }^{\circ} \mathrm{C}\right)$ & 28.9 & 38.3 & 32.9 \\
\hline Time to reach maximum temperature $(\mathrm{h})$ & 72 & 72 & 108 \\
\hline
\end{tabular}

avalues were calculated from the temperature curve

Table 4: Growth kinetic parameters ${ }^{a}$ at various initial galactose concentrations.

was studied in Table 4. The sugar solution was prepared by dissolving the required galactose weight in the appropriate volume of deionized distilled water and then autoclaving (Model No. STM-E, Market Forge Sterilmatic, New York, USA) at $121^{\circ} \mathrm{C}$ and $103.4 \mathrm{kPa}$ for $30 \mathrm{~min}$. Each reactor was loaded up to $75 \%$ of its capacity ( $200 \mathrm{~g}$ shells based on dry weight). The initial moisture content of the shrimp shells was adjusted to $60 \%$ with the addition of sugar and spores solutions and the material was mixed thoroughly. An inoculum concentration of $1 \times 10^{7}$ spores per $1 \mathrm{~g}$ shrimp shell waste was used. Air was introduced inside each reactor at a flow rate of $5 \mathrm{VMM}$ ( $\mathrm{ml}$ air per $\mathrm{g}$ shells per minute). The experiment ran for 6 days. At the start of the experiment, the reactors were rotated $(1 \mathrm{rpm})$ continuously for $30 \mathrm{~min}$ and then intermittently for 15 min every hour.

\section{Experimental analyses}

The particle size distribution, moisture content, $\mathrm{pH}$, galactose concentration, ammonium nitrogen, total Kjeldahl nitrogen, protein and chitin were performed on the shrimp shells. During the course of the fermentation period, shrimp shell samples of $10 \mathrm{~g}$ each were collected every $12 \mathrm{~h}$ and analyzed for moisture content, $\mathrm{pH}$, galactose concentration, protease activity, ammonium nitrogen, total Kjeldahl nitrogen and protein. Exhaust gas samples were also taken every $12 \mathrm{~h}$ and analyzed for carbon dioxide concentration. The bulk temperature was monitored and recorded every 10 minutes. The deproteinized shells were analyzed for chitin and appearance.

Particle size distribution: A known weight of shrimp shells was sieved for 30 min using a sieve shaker (Model RX-86, Fisher Scientific, Montreal, Quebec, Canada) with 7 different sieve sizes (6.300, 4.000, $2.000,0.850,0.300,0.180,0.075 \mathrm{~mm}$ aperture size). Each particle size fraction obtained was weighed and the percentage from the total weight was calculated.

Moisture contents: A known weight of shrimp shells was placed in a pre-weighed aluminum dish. The dish and content were weighed and then placed in a convection oven (Isotemp Oven, Model 655F,
Fisher Scientific, Montreal, Quebec, Canada) at $105^{\circ} \mathrm{C}$ for 24 hours. The aluminum dish along with the dried sample were first placed in a desiccator to cool down and then weighed. The moisture content was determined as follows:

$$
M C=\frac{W_{w s}-W_{d s}}{W_{w s}} \times 100
$$

Where:

MC is the moisture content (\%)

Wws is the weight of the wet sample (g)

$\mathrm{Wds}$ is the weight of the dry sample (g)

pH: $20 \mathrm{ml}$ of deionized distilled water was added to one gram of shrimp shell sample and kept at room temperature $\left(21^{\circ} \mathrm{C}\right)$ for 30 min with frequent stirring using a stir plate (Thermix ${ }^{\circ}$ Stirrer Model 120MR, Fisher Scientific, Montreal, Quebec, Canada). The sample was let stand for 2 minutes and the $\mathrm{pH}$ was then measured using a $\mathrm{pH}$ meter (Model 805MP, Fisher Scientific, Montreal, Quebec, Canada).

Ammonium nitrogen: Samples were washed thoroughly several times with deionized distilled water until the wash water was clear and then dried in an oven (Isotemp Oven, Model 655F, Fisher Scientific, Montreal, Quebec, Canada) at $60^{\circ} \mathrm{C}$ till constant weight. The dried shells were ground using a small conventional grinder (Hamilton Beach, Markham, Ontario, Canada). Ammonium nitrogen $\left(\mathrm{NH}^{4}-\mathrm{N}\right)$ of dry ground samples was determined directly using a nitrogen analysis system (KJELTEC AUTO 1030 Analyzer, Fisher Scientific, Montreal, Quebec, Canada).

Total Kjeldahl nitrogen: Samples were washed thoroughly several times with deionized distilled water until the wash water was clear and then dried in an oven (Isotemp Oven, Model 655F, Fisher Scientific, Montreal, Quebec, Canada) at $60^{\circ} \mathrm{C}$ till constant weight. The dried shells were ground using a small conventional grinder (Hamilton Beach, Markham, Ontario, Canada) and then digested by heating the sample with concentrated sulfuric acid and Kjeltabs (which contained $3.5 \mathrm{~g} \mathrm{~K}_{2} \mathrm{SO}_{4}$ and $0.0035 \mathrm{Se}$ ) for $45 \mathrm{~min}$. The $\mathrm{K}_{2} \mathrm{SO}_{4}$ promotes the oxidation of organic matter and conversion of organic nitrogen to ammonium nitrogen by increasing the temperature of the digest $\left(420^{\circ} \mathrm{C}\right)$. Se is a catalyst which increases the rate of oxidation of organic matter by sulfuric acid. $5 \mathrm{ml}$ sulfuric acid with $1 \mathrm{Kjeltab}$ per $0.2 \mathrm{~g}$ dry weight sample was used in this study. The total Kjeldahl nitrogen (TKN) of the digested samples was as determined using nitrogen analysis system (KJELTEC AUTO 1030 Analyzer, Fisher Scientific, Montreal, Quebec, Canada).

\section{Protein}

The protein content of the samples was determined using the following equations which are based on the fact that the protein contains about $16 \%$ nitrogen:

(Org.- $\mathrm{N}) \mathrm{s}=\mathrm{TKNs}-\left(\mathrm{NH}_{4}-\mathrm{N}\right) \mathrm{s}$

$\mathrm{PRc}=[($ Org. $-\mathrm{N}) \mathrm{s}-($ Org. $-\mathrm{N}) \mathrm{c}] \times 6.25$

Where:

$\mathrm{PRc}$ is protein content $(\mathrm{mg} / \mathrm{kg})$

(Org.-N)c is organic nitrogen of the recovered chitin $(\mathrm{mg} / \mathrm{kg})$

(Org.-N)s is organic nitrogen of the sample $(\mathrm{mg} / \mathrm{kg})$

TKNs is total Kjeldahl nitrogen of the sample $(\mathrm{mg} / \mathrm{kg})$

$\left(\mathrm{NH}_{4}-\mathrm{N}\right) \mathrm{s} \quad$ is ammonium nitrogen of the sample $(\mathrm{mg} / \mathrm{kg})$ 
Galactose concentration: $20 \mathrm{ml}$ of deionized distilled water was added to one gram of fermented shrimp shell sample and kept at room temperature $\left(21^{\circ} \mathrm{C}\right)$ for $30 \mathrm{~min}$ with frequent stirring using a stir plate (Thermix ${ }^{\oplus}$ Stirrer Model 120MR, Fisher Scientific, Montreal, Quebec, Canada). The extract was then filtered under suction using coarse porosity filter paper (Reeve Angel Grade 202, Whatman Inc., Clifton, New Jersey, USA) and the supernatant was used for galactose concentration measurements using the phenol-sulfuric acid method which is based on the fact that simple sugars give a stable orange-yellow color when react with phenol and concentrated sulfuric acid [11]. The intensity of the color is proportional to the amount of galactose present in the sample and can be measured at $492 \mathrm{~nm}$.

First, a standard curve was developed from solutions of galactose and deionized distilled water with different concentrations. First, a standard solution of $100 \mu \mathrm{g} / \mathrm{ml}$ galactose was prepared by dissolving $10 \mathrm{mg}$ galactose in $100 \mathrm{ml}$ deionized distilled water. Then, a set of 6 solutions with galactose concentration of $5,10,15,20,25$, and 30 $\mu \mathrm{g} / \mathrm{ml}$ were prepared. Finally, the absorbance was measured using a microplate reader ( $\mu$ Quant, Bio-Tek Instruments, Inc., Winooski, Vermont, USA) at $492 \mathrm{~nm}$. A blank sample of pure deionized distilled water was used. The measured absorbance was plotted against the known galactose concentrations $(\mu \mathrm{g} / \mathrm{ml})$ as shown in Figure 3 . The following linear relationship between the galactose concentration and the absorbance was obtained $\left(\mathrm{R}^{2}=0.98\right)$ :

$$
\mathrm{C}_{\mathrm{ga}}=416.67\left(\overline{\mathrm{A}}_{492}\right)
$$

Where:

$$
\mathrm{C}_{\mathrm{ga}} \quad \text { is the galactose concentration }(\mu \mathrm{g} / \mathrm{ml})
$$

For measuring the galactose in the shrimp shells, $2 \mathrm{ml}$ of the extract of each sample were transferred to a test tube and $1 \mathrm{ml}$ of phenol solution and $5 \mathrm{ml}$ of concentrated sulfuric acid (95-98\%) were added to the tube. The tubes were then tight capped and the contents were mixed using a vortex mixer (Sybron Maxi Mix Model M-16715, Thermolyne Corporation, Dubuque Iowa, USA). The tubes were allowed to stand for 10 minutes at room temperature and then the contents were mixed again using a vortex mixer. The tubes were placed in a water bath at $30^{\circ} \mathrm{C}$ for 15 minutes after which the contents were mixed again using a vortex mixer. The tubes were allowed to stand for 30 minutes at room temperature. $200 \mu \mathrm{l}$ of each tube were carefully loaded into duplicate wells in a microliter plate and the absorbance was measured using a microplate reader ( $\mu$ Quant, BioTek Instruments, Inc., Winooski, Vermont, USA).

Protease activity: Protease produced by $A$. niger was first extracted from the samples ( $1 \mathrm{~g}$ each) using $20 \mathrm{ml}$ deionized distilled water and kept at room temperature $\left(21^{\circ} \mathrm{C}\right)$ for $30 \mathrm{~min}$ with continuous stirring using a stir plate (Thermix ${ }^{\otimes}$ Stirrer Model $120 \mathrm{MR}$, Fisher Scientific, Montreal, Quebec, Canada). The extract was then filtered under suction using coarse porosity filter paper (Reeve Angel Grade 202, Whatman Inc., Clifton, New Jersey, USA) and the supernatant was used for the assay of enzyme. Protease activity was measured using Protease Colorimetric Detection Kit (Product Code PC0100, Sigma, St. Louis, Missouri, USA). The assay was based on using a casein substrate, which is cleaved by the protease to trichloroacetic acid soluble peptides. The formed peptides contain tyrosine and tryptophan residues, which react with the Folin and Ciocalteu's reagent causing color change, which can be estimated calorimetrically at $660 \mathrm{~nm}$ using a microplate reader ( $\mu$ Quant, Bio-Tek Instruments, Inc., Winooski, Vermont, USA).

Chitin: The chitin content was determined based on the fact that chitin contains about $6.89 \%$ organic nitrogen [12]. In order to determine the chitin nitrogen, samples were first deproteinized and demineralized. The deproteinization process was performed using $5 \%(\mathrm{w} / \mathrm{v}) \mathrm{NaOH}$ solution. One gram of ground shrimp shell sample (dry weight) along with $100 \mathrm{ml}$ of $\mathrm{NaOH}$ solution were placed in a 250 $\mathrm{ml}$ wide-mouth flask and the flask was covered with a piece of tin foil and sealed with a rubber band to ensure the retention of all reacted materials. The flask was then placed in a boiling water bath for $1 \mathrm{~h}$. The sample was filtered under suction through a Buchner funnel with coarse porosity filter paper (Reeve Angel Grade 202, Whatman Inc., Clifton, New Jersey, USA) and washed thoroughly with deionized distilled water. The deproteinized sample was dried in an oven (Isotemp Oven, Model 655F, Fisher Scientific, Montreal, Quebec, Canada) at $60^{\circ} \mathrm{C}$ till constant weight. The weight of the recovered dry deproteinized sample was determined.

The deproteinized sample along with $50 \mathrm{ml}$ of $1.0 \mathrm{M} \mathrm{HCl}$ were placed in a $250 \mathrm{ml}$ wide-mouth flask and the flask was covered with a piece of tin foil and sealed with a rubber band to ensure the retention of all reacted materials The flask was then placed in a boiling water bath for $1 \mathrm{~h}$. The demineralized sample was then filtered under suction through a Buchner funnel with coarse porosity filter paper (Reeve Angel Grade 202, Whatman Inc., Clifton, New Jersey, USA) and washed thoroughly with deionized distilled water. The deproteinized-demineralized sample was then dried in an oven (Isotemp Oven, Model 655F, Fisher Scientific, Montreal, Quebec, Canada) at $60^{\circ} \mathrm{C}$ till constant weight. The weight of the recovered dry deproteinized-demineralized sample was determined. The ammonium and total Kejldahl nitrogen analysss were performed on the dry deproteinized-demineralized sample and the chitin content was then calculated as follows:

$($ Org. $-\mathrm{N}) \mathrm{c}=\left[\left(\mathrm{TKNc}-\left(\mathrm{NH}_{4}-\mathrm{N}\right) \mathrm{c}\right] \times \mathrm{Wc} / \mathrm{Ws}\right.$

$\mathrm{CHc}=($ Org. $-\mathrm{N}) \mathrm{c} \times 14.51$

Where:

$\mathrm{CHc} \quad$ is chitin content $(\mathrm{mg} / \mathrm{kg})$

(Org.-N)c is organic nitrogen of the recovered chitin

$\mathrm{TKNc}$ is total Kjeldahl nitrogen of the recovered chitin $(\mathrm{mg} / \mathrm{kg})$

$\left(\mathrm{NH}_{4}-\mathrm{N}\right) \mathrm{c}$ is ammonium nitrogen of the recovered chitin $(\mathrm{mg} / \mathrm{kg})$

Wc is weight of recovered chitin $(\mathrm{g})$

Ws is weight of sample (g)

Visualization of shrimp shells: The shrimp shells were visually inspected at the end of the deproteinization with the naked eye as well

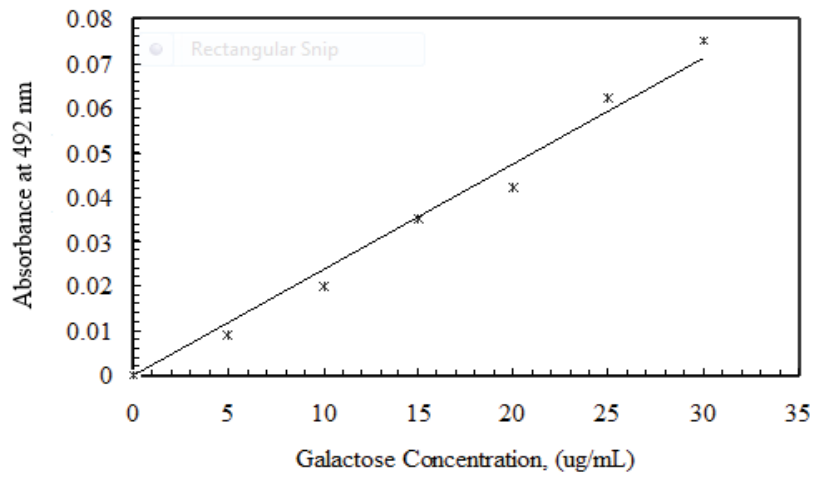

Figure 3: Galactose concentration standard curve. 


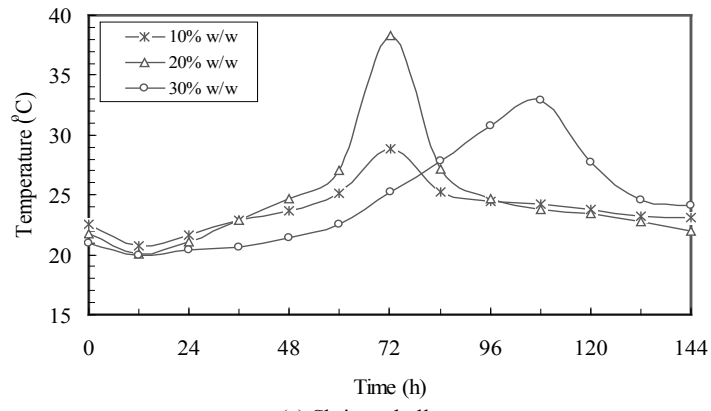

(a) Shrimp shell

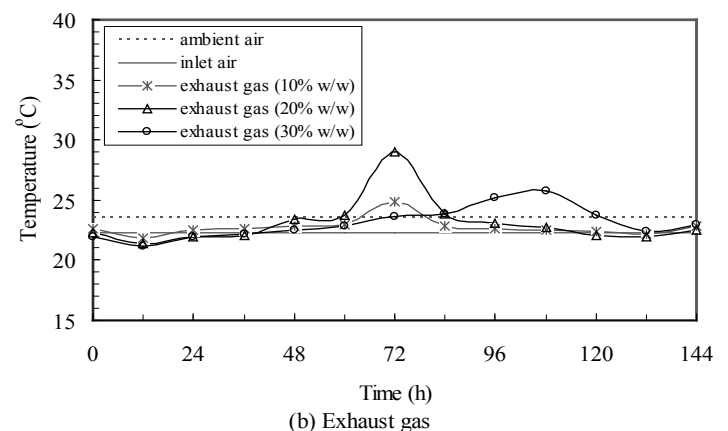

Figure 4: Effect of initial galactose concentration on the temperatures of shrimp shells and exhaust gas.

as under the incident light stereomicroscope (Carl Zeiss Stemi SV8, Carl Zeiss Canada, Toronto, Ontario, Canada) at a magnification of $60 \mathrm{X}$. The stereoscope was equipped with a cold light source (SCOHTT KL 1500, SCHOTT North America Inc., New York, USA) and a single chip CCD color video camera (Sony DXC-101, Sony of Canada, Toronto, Ontario, Canada).

\section{Results and Discussion}

The effects of initial galactose concentration on the kinetic parameters of the deproteinization process (temperature, $\mathrm{pH}$, moisture content, galactose utilization, carbon dioxide evolution, protease activity, residual protein and chitin concentration) were investigated.

\section{Temperature}

Figure 4 shows the change in the temperatures of the shrimp shells and the exhaust gas during the course of deproteinization as affected by initial galactose concentration. The values are the average of three replicates. The coefficient of variation ranged from 0.87 to $6.03 \%$.

The deprotinzation of shrimp shells in the presence of galactose as a carbon source is an exothermic reaction. The fungus utilize organic matter for the synthesis of new microbial cells (population growth), product formation and respiration (energy production) [7,13]. The heat stored in a bioreactor during the fermentation process is the net of metabolic heat produced by microbial activity minus the heat losses (by conduction from the bioreactor walls, convection with the exhaust gas and latent heat for evaporation of water). The temperature of the fermentation medium will increase as a result of heat accumulation in the bioreactor.

In this study, the temperature of the shrimp shells decreased in the first 12 hours because heat loses due to the evaporation of water (latent heat) and the cooling effect of the inlet air were higher than the heat generation in the bioreactor as the microorganisms were still adapting to the new environment during the initial lag period. The temperature of the shrimp shell then increased as a result of heat accumulation in the bioreactor reaching maximum temperatures of 28.9, 38.3 and $32.9^{\circ} \mathrm{C}$ after 72,72 and $108 \mathrm{~h}$ for the 10,20 and $30 \% \mathrm{w} / \mathrm{w}$ initial galactose concentrations, respectively. The results showed that the maximum temperature attained at the initial galactose concentration of $20 \%$ w/w was much higher than those attained with the initial galactose concentration of 10 and $30 \% \mathrm{w} / \mathrm{w}$. This indicated that galactose of $10 \% \mathrm{w} / \mathrm{w}$ was a limiting factor for microbial growth and the galactose concentration of $30 \% \mathrm{w} / \mathrm{w}$ caused inhibition.

The exhaust gas temperature profiles were similar to those of the shrimp shells. The rise in the exhaust gas temperature after $12 \mathrm{~h}$ was due to heat losses from shrimp shells by convection with exhaust gas and water vapor. The temperature of the exhaust gas reached maximum values of $24.9,29.0$ and $25.8^{\circ} \mathrm{C}$ after 72,72 and $108 \mathrm{~h}$ for the initial galactose concentrations of 10,20 and $30 \%$, respectively.

Several authors reported on the temperature rise in bioreactors during solid-state fermentation. Gowthaman et al. [14] obtained a similar temperature profile for the production of amyloglucosidase from wheat bran by A. niger in a solid-state fermentation. Pandey [15] reported a maximum substrate temperature of $41^{\circ} \mathrm{C}$ for the production of the enzyme.

Glucoamylase from wheat bran using A. niger in a solid-state fermentation. Ghildyal et al. [14], Ghildyal et al. [16] and Pandey [17] found the temperatures in the middle of the bed to about $20^{\circ} \mathrm{C}$ higher than the temperature of the inlet air. In the current study, the peak temperature of the shells material was about 7,17 and $11^{\circ} \mathrm{C}$ higher than the inlet air temperature for the initial galactose concentration of 10,20 , and $30 \% \mathrm{w} / \mathrm{w}$, respectively.Rathbun and Shuler [18] reported a temperature gradient of $3^{\circ} \mathrm{C} / \mathrm{cm}$ within a bed depth of $6.35 \mathrm{~cm}$ when fermenting soybeans using Rhiopus oligosporus. Saucedo-Castañeda et al. [19] reported an axial temperature gradient of $0.17^{\circ} \mathrm{C} / \mathrm{cm}$ and a radial temperature gradient of $5^{\circ} \mathrm{C} / \mathrm{cm}$ during the fermentation of cassava using $A$. niger. There were no temperature gradients in the radial or axial direction in this study due to mixing.

A typical batch growth curve (Figure 5) includes: (a) a lag phase, during which microbial population adapt to the surrounding environment, (b) an exponential growth phase, during which the microbial population increase exponentially (c) a deceleration growth phase, during which growth decelerates because of the depletion of essential nutrients and/or the accumulation of inhibitory products, (d) a stationary phase, during which the net growth rate is zero as a result

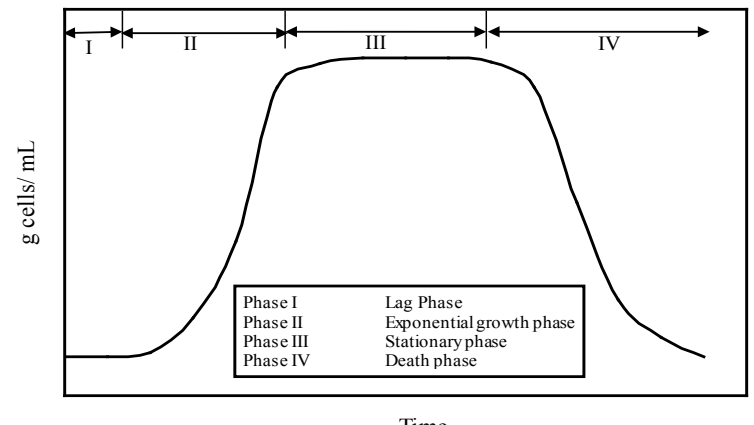

Time

Figure 5: Typical batch growth curve. 
of the balancing of cell reproduction rate by an equivalent cell death rate and (e) a death phase, during which cells die faster than new cells are produced. Ben-Hassan et al. [20] and Ghaly et al. [21] stated that the microbial growth and the temperature curves are similar in shape and the temperature curve can be used to determine microbial kinetics. Table 3 shows some of the kinetic parameters calculated from the shrimp shell temperature curve. The lag phase and the specific growth rate were determined graphically according to the procedure described by Ghaly et al. [22]

No significant differences in the lag period $(12 \mathrm{~h})$ were observed when the galactose concentration was increased from 10 to $30 \% \mathrm{w} / \mathrm{w}$. Also, no change in the length of the exponential growth phase $(60 \mathrm{~h})$ was observed when the galactose concentration was increased from 10 to $20 \% \mathrm{w} / \mathrm{w}$ but a further increase in the galactose concentration to $30 \% \mathrm{w} / \mathrm{w}$ increased the length of the exponential growth phase to 96 $\mathrm{h}$. The stationary phase increased from 2 to $5 \mathrm{~h}$ as the initial galactose concentration was increased from 10 to $20 \% \mathrm{w} / \mathrm{w}$ and then to $11 \mathrm{~h}$ with a further increase in the initial galactose concentration to $30 \% \mathrm{w} / \mathrm{w}$.

The specific growth rates for $A$. niger were $0.0042,0.0089$ and $0.0058 / \mathrm{h}$ for the initial galactose concentrations of 10,20 and $30 \%$, respectively. These were lower than that of $0.29 / \mathrm{h}$ reported by Esfahani et al. [23] and that of $0.2 / \mathrm{h}$ reported by Pedersen et al. [24]. The low specific growth values obtained in this study could be due to temperature activation. Szewczyk and Myszka [25] studied the effect of temperature on the growth of A. niger in solid-state fermentation and found that the net growth constant started to decrease at temperatures above $32^{\circ} \mathrm{C}$ as a result of temperature deactivation. Yang and Chiu [26] reported that the mycelial growth had maximal temperature value at $26^{\circ} \mathrm{C}$ and recommended the cultivation of $A$. niger at $25-30^{\circ} \mathrm{C}$ for $24 \mathrm{~h}$ for mycelium propagation and then adjusting the temperature to 20 $25^{\circ} \mathrm{C}$ for maximal protease production.

\section{pH}

Figure 6 shows the change in $\mathrm{pH}$ during the course of deproteinization as affected by the initial galactose concentration. The values are the average of three replicates. The coefficient of variation ranged from 0.92 to $5.16 \%$.

The $\mathrm{pH}$ of the shrimp shells decreased with time up to a certain value and then increased again. The lowest $\mathrm{pH}$ of $6.55,6.63$ and 5.92 were reached after 36,72 and $108 \mathrm{~h}$ of deproteinization which then increase reaching $8.32,7.9$ and 6.28 by the end of the deproteinization process $(144 \mathrm{~h})$ for the initial galactose concentrations of 10,20 and $30 \% \mathrm{w} / \mathrm{w}$, respectively. Zakaria et al. [2] reported a drop in the $\mathrm{pH}$ to 5 over the first $48 \mathrm{~h}$ of lactic acid fermentation of scampi waste after which it increased reaching a value of 6.6 as a result of the buffering capacity of the solubilized calcium. Beaney et al. [27] reported a rapid decrease in $\mathrm{pH}$ to 3.5 over 7 days during lactic acid fermentation of prawn shells as a result of metabolic lactic acid production. Teng et al. [4] reported decreases in the medium $\mathrm{pH}$ to 3-6 as a result of shrimp shells deproteinization by $A$. niger. In this study, the observed decrease in the $\mathrm{pH}$ of the shrimp shells was due to acid protease production while the increase in the $\mathrm{pH}$ of the shrimp shells was due to the buffering capacity of the calcium carbonate released from the shrimp shells $[2,28]$ and/or the production of ammonium nitrogen [29]. Villegas et al. [30] and Andrade et al. [31] stated that changes in $\mathrm{pH}$ due to the growth of microorganisms are linked to the ionic balance established by substrate uptake and product formation.

\section{Moisture Content}

Figure 7 shows the change in moisture content of the shrimp shells during the course of deproteinization as affected by initial galactose concentration. The values are the average of three replicates. The coefficient of variation ranged from 1.04 to $8.97 \%$.

The initial moisture content of $60 \%$ declined with time reaching $43.71,36.20$ and $25.91 \%$ by the end of the deproteinization process for the galactose concentrations of 10,20 and $30 \% \mathrm{w} / \mathrm{w}$, respectively. The net moisture content of the shrimp shell bed is the initial moisture content plus the moisture contribution of metabolic activity minus the moisture lost by evaporation with the exhaust gas. The initial decrease in the moisture content indicated that moisture lost through evaporation exceeded the metabolic water production.

Yang and Chiu [26] and Yang and Ling [28] reported that low moisture content caused the substrate to be too dry for microbial growth and product formation and high moisture content caused packing of the substrate and prevention of gas exchange. Diaz et al. [32] reported that microbial activity became inhibited as the moisture content decreases below $40 \%$ and completely ceased when moisture content reached $8-12 \%$. Yang and Chiu [26] reported optimum initial moisture contents for $A$. niger between $50-58 \%$ for the production of protease by solid-state fermentation of sweet potato residue. In this study, the initial moisture content of the shrimp shells was adjusted to $60 \%$, which fell below $40 \%$ after 84 and $108 \mathrm{~h}$ of deproteinization for the initial galactose concentrations of 20 and $30 \% \mathrm{w} / \mathrm{w}$, respectively. In order to maintain the moisture content in the bioreactor at the desired level, the exhaust gas should be passed through a condensation tower and the recovered water pumped back into the bioreactor through the aeration tube.

\section{Galactose utilization}

Figure 8 shows the effect of initial galactose concentration on the

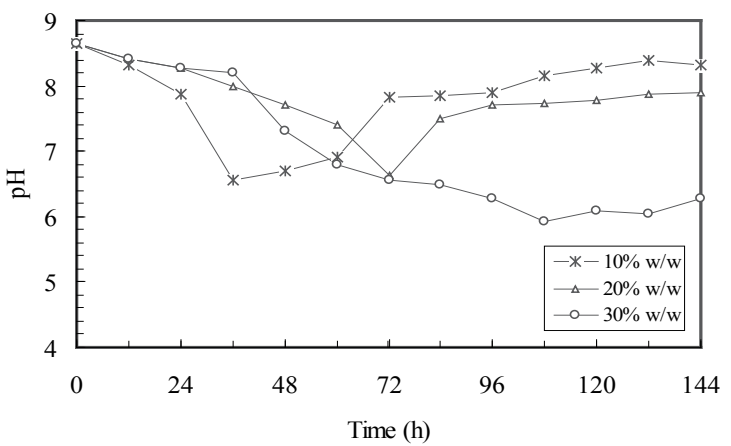

Figure 6: Effect of initial galactose concentration on $\mathrm{pH}$.

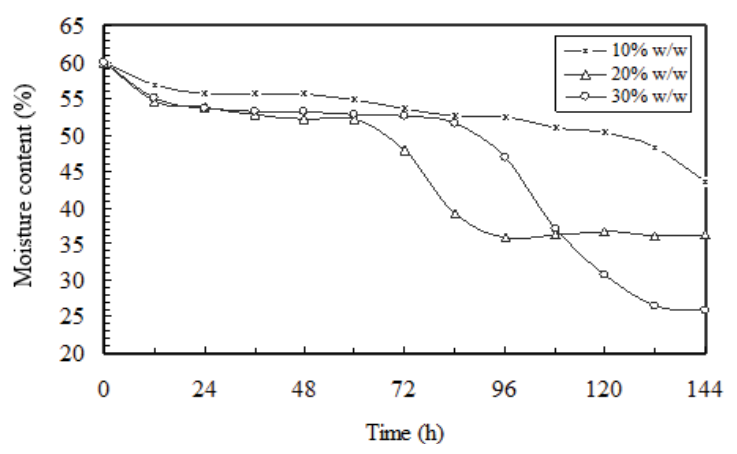

Figure 7: Effect of initial galactose concentration on moisture content 


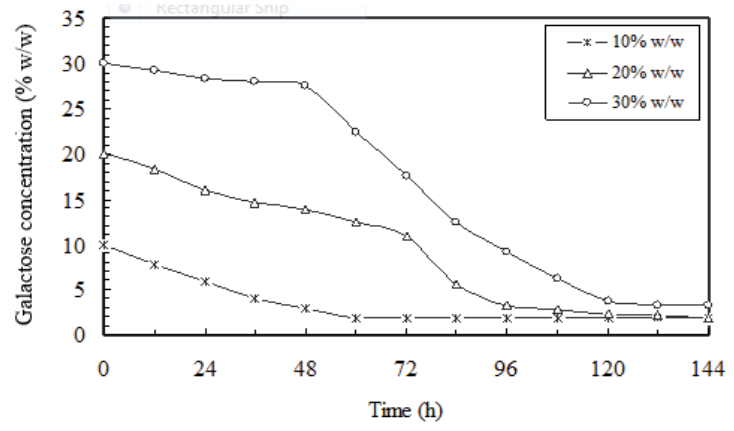

Figure 8: Effect of initial galactose concentration on residual galactose concentarion.

residual galactose concentration in the shrimp shells during the course of deproteinization. The values are the average of three replicates. The coefficient of variation ranged from 3.77 to $11.71 \%$. The galactose concentration in the bioreactor decreased with time. For the run with the initial galactose concentration of $10 \% \mathrm{w} / \mathrm{w}$, the galactose consumption was rapid and about $85.0 \%$ of the galactose was utilized after $72 \mathrm{~h}$ of deproteinization. For the run with the initial galactose concentration of $20 \%$, the galactose consumption was gradual and about 40 of galactose was utilized during the first $72 \mathrm{~h}$. Thereafter, the galactose consumption became rapid and reached $85.0 \%$ after $96 \mathrm{~h}$ of deproteinization. For the run with the initial galactose concentration of $30 \% \mathrm{w} / \mathrm{w}$, the galactose consumption was slow and about $8.5 \%$ of galactose was utilized over the first $48 \mathrm{~h}$ indicating substrate inhibition. It then became rapid reaching $87.3 \%$ after $120 \mathrm{~h}$ of deproteinization. By the end of the experiment, about $91.0,91.0$ and $88.35 \%$ of the initial galactose of 10, 20 and $30 \% \mathrm{w} / \mathrm{w}$ were utilized, respectively.

Andrade et al. [31] studied the effect of initial D-glucose concentrations $(40,60$ and $80 \mathrm{~g} / \mathrm{L})$ on the production of extracellular proteases by Mucor circinelloides and noted that at high D-glucose concentrations ( 60 and $80 \mathrm{~g} / \mathrm{L}$ ), the substrate was not totally consumed while at low D-glucose concentration $(40 \mathrm{~g} / \mathrm{L})$ no residual glucose was detected by the end of cultivation period $(96 \mathrm{~h})$. Haq et al. [33] reported $58.67 \%$ sucrose utilization after $144 \mathrm{~h}$ incubation during citric acid production using A. niger.

\section{Carbon dioxide evolution}

Figure 9 shows the effect of initial galactose concentration on carbon dioxide concentration in the exhaust gas. The values are the average of three replicates. The coefficient of variation ranged from 1.29 to $8.56 \%$. The carbon dioxide increased with time from the initial value of $0.02 \%$ to $0.16,0.56$ and $0.32 \%$ after 72,72 and $104 \mathrm{~h}$ and then declined reaching $0.06,0.08$ and $1.02 \%$ by the end of the experiment for the runs with the initial galactose concentrations of 10, 20 and 30 $\%$, respectively.

Temperature rise and carbon dioxide evolution are indicators of microbial activity. Several authors used metabolic heat and CO2 evolution as indirect methods for biomass quantification during solid-state fermentation $[18,34,35]$. The carbon dioxide profiles and temperature profiles obtained in this study were similar and the results showed a strong correlation between the concentrations of carbon dioxide in the exhaust gas and the temperature of the shrimp shells (Figure 10). Gowthaman et al. [14] also obtained a $\mathrm{CO}_{2}$ profile similar to the temperature profile during solid-state fermentation of wheat bran using $A$. niger for the production of amyloglucosidase.

\section{Protease activity}

Figure 11 shows the effect of initial galactose concentration on protease activity during the course of deproteinization. The values are presented in units per gram dry shrimp shells. One unit of protease activity was defined as the amount of enzyme which can hydrolyze casein to produce color (color by Folin Ciocalteu's Reagent) equivalent to $1.0 \mu$ mole $(181 \mu \mathrm{g})$ of tyrosine per minute at $\mathrm{pH} 7.5$ and a temperature of $370 \mathrm{C}$. The values are the average of three replicates. The coefficient of variation ranged from 2.69 to $9.52 \%$.

The protease activity increased gradually with time from an initial value of $0.71 \mathrm{U} / \mathrm{g}$ (dry weight) reaching 1.82, 1.85 and 1.77 unit/gram (dry weight) after $144 \mathrm{~h}$ for the 10, 20 and $30 \% \mathrm{w} / \mathrm{w}$ initial galactose concentrations, respectively. The protease activities for the initial galactose concentration of $20 \% \mathrm{w} / \mathrm{w}$ was higher than those for the initial galactose concentrations of 10 and 30\% w/w. Andrade et al. [31] reported a decrease in the yield factor for protease and an increase in the yield factor for biomass with increasing the initial D-glucose concentration from 40 to $80 \mathrm{~g} / \mathrm{L}$ indicating a catabolic repression.

Teng et al. [4] screened 34 fungal strains for their proteolytic activity and concluded that $A$. niger strains gave higher protease activity compared to the other strains. Protease activities in the range of $0.8-6.8$ units (one unit activity was defined as $1 \mu \mathrm{M}$ of tyrosine produced in 1 min) for $17 \mathrm{~A}$. niger strains after 5 days of incubation of the spores at $25^{\circ} \mathrm{C}$ and $200 \mathrm{rpm}$ in a medium having a $\mathrm{pH}$ of 7.4 and containing $1.0 \%$ casein, $0.4 \%$ D-glucose, $0.4 \%$ yeast extract, $1.0 \mathrm{~g} / \mathrm{L} \mathrm{K}_{2} \mathrm{HPO}_{4} .3 \mathrm{H}_{2} \mathrm{O}, 0.5$ $\mathrm{g} / \mathrm{L} \mathrm{MgSO} 4.7 \mathrm{H} 2 \mathrm{O}$ and $0.1 \mathrm{ml} / \mathrm{L}$ Vogel trace element solution.

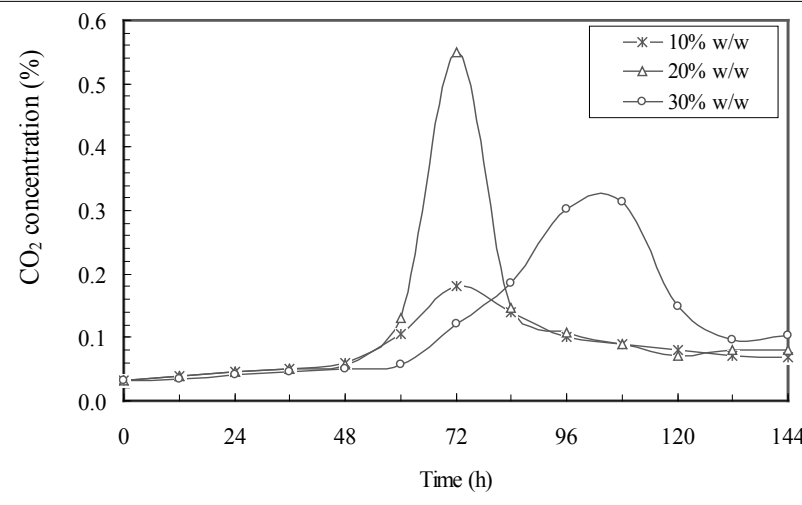

Figure 9: Effect of initial galactose concentration on carbon dioxide concentration in the exhaust gas.

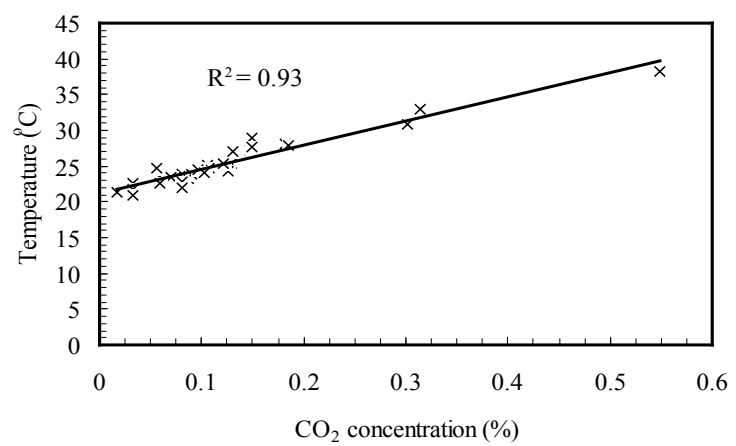

Figure 10: Correlation between the carbon dioxide concentration in the exhaust gas and and temperature of the shrimp shells. 


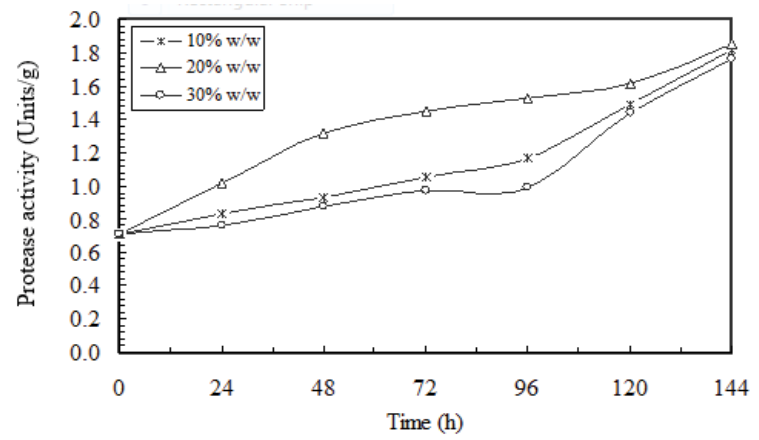

Figure 11: Effect of initial galactose concentration on protease activity.

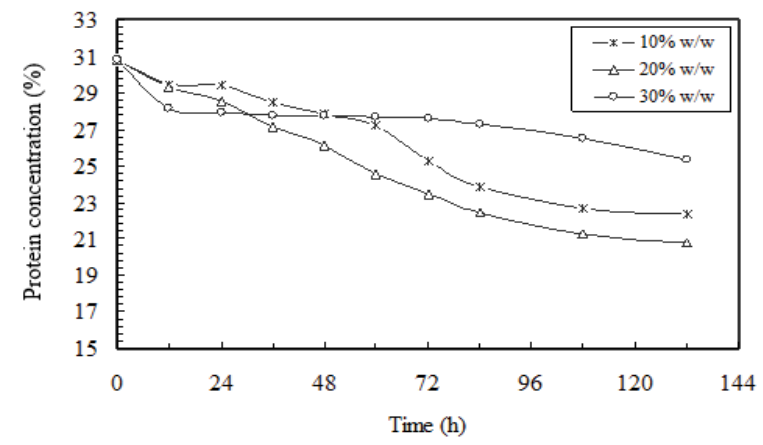

Figure 12: Effect of initial galactose concentration on residual protein concentration.

Ashour et al. [36] reported increased protease yield from A. niger with incubation time during cheese whey fermentation which reached a maximum value after 6 days. Ray et al. [37] reported that protease production was greater during the exponential growth phase of the yeast Candida humicola. Bulthuis et al. [38] reported a predominant protease production during the logarithmic phase and and low but steady production during the stationary phase of Bacillus licheniformis.

\section{Protein concentration}

Figure 12 shows the effect of initial galactose concentration on residual protein in the shrimp shells during the deproteinization process. The values are presented based on the dry weight of the samples. The values are the average of three replicates. The coefficient of variation ranged from 2.19 to $7.51 \%$.

The protein concentration in the shrimp shells decreased with time as a result of protein break down by the proteolytic enzymes produced by $A$. niger. It decreased from the initial value of $30.84 \%$ to final values of $22.34,20.77$, and $25.30 \%$ after $132 \mathrm{~h}$ of deproteinization for the 10 , 20 and $30 \% \mathrm{w} / \mathrm{w}$ initial galactose concentrations, respectively. The highest protein removal efficiency (33.33\%) was achieved with initial galactose concentration of $20 \% \mathrm{w} / \mathrm{w}$.

Beaney et al. [27] reported 50\% decrease in protein concentration in prawn shell waste using lactic acid fermentation and stated that complete biological deproteinization seems hard to achieve. The low deproteinization efficiency observed in this study could be due to: (a) the large particle size of the shrimp shells, (b) the high $\mathrm{pH}$ of the shrimp shells that might have interfered with protease synthesis and/or activity, (c) protein denaturation that might have happen during autoclaving of shrimp shells and (d) the high temperature in the bioreactor that might have interfered with protease synthesis and/or activity.

\section{Chitin concentration}

Figure 13 shows the effect of initial galactose concentration on chitin content of the shrimp shells during the deproteinization process. The shrimp shells used in this study contained $31.73 \%$ minerals. The chitin concentration values are based on the dry weight of the samples and were determined for the deproteinized samples without demineralization. The values are the average of three replicates. The coefficient of variation ranged from 1.89 to $7.22 \%$.The chitin concentration in the shrimp shells increased with time as a result of protein removal. It increased from an initial value of $16.59 \%$ to final values of $20.48,21.99$, and $20.24 \%$ after $132 \mathrm{~h}$ of deproteinization for the 10,20 and $30 \% \mathrm{w} / \mathrm{w}$ initial galactose concentrations, respectively. Zakaria et al. [2] reported an increase in the chitin concentration (from 12.05 to $17.48 \%$ ) as a result of lactic acid fermentation of scampi waste. Cira et al. [39] reported increases in chitin concentrations (from 11.4$13.1 \%$ to $20.3-23.2 \%$ ) as a result of lactic acid fermentation of shrimp waste.

\section{Visualization of shrimp shells}

Figure 14 shows the effect of initial galactose concentration on the visual appearance of the shrimp shells at the end of the deproteinization process $(144 \mathrm{~h})$. The spent shrimp shells obtained from the run that received the $10 \%$ initial galactose concentration had a pale pink-orange color with a fair amount of moisture remaining. The spent shrimp shells obtained from the run that received $20 \%$ initial galactose concentration had a pale pink-orange color with some tan patches and appeared a little dryer compared to those obtained from the run that received the $10 \%$ initial galactose concentration. The existence of the pink-orange color in these two runs was an indication of the presence of pigments which were not utilized during the fermentation process. The spent shrimp shells obtained from the run that received the $30 \%$ initial galactose concentration appeared very dry and had a gray-black color due to the presence of $A$. niger spores. The high galactose concentration (30\%) inhibited the growth of $A$. niger and enhanced sporulation. Beaney et al. [26] compared chitin purified by lactic acid fermentation and chitin extracted by a chemical method and reported that the color of extracted chitin using lactic acid fermentation ranged from pale pink-orange to off-white with tan tones due to the presence of impurities such as pigments and proteins in the extracted chitin. However, they reported a light tan color for chitin extracted by the chemical method as a result of the removal or degradation of most of the pigments.

The spent shells were also inspected under the microscope at $60 \mathrm{X}$ magnification (Figure 15). Some white precipitants were noticed on the shells obtained from the runs that received initial galactose concentrations of 10 and $20 \% \mathrm{w} / \mathrm{w}$. The white precipitants were more

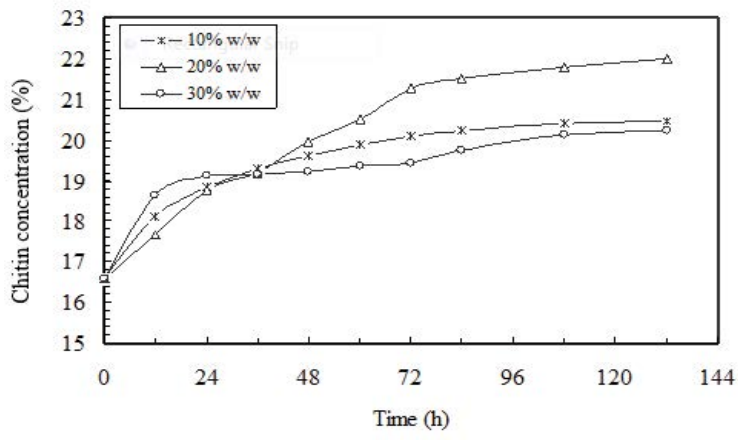

Figure 13: Effect of initial galactose on chitin concentration. 


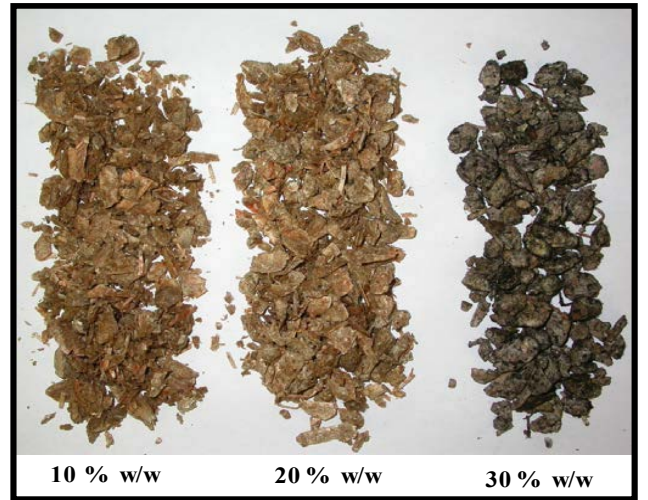

Figure 14: Shrimp shells after $144 \mathrm{~h}$ of deproteinization as affected by the initial galactose concentrations.
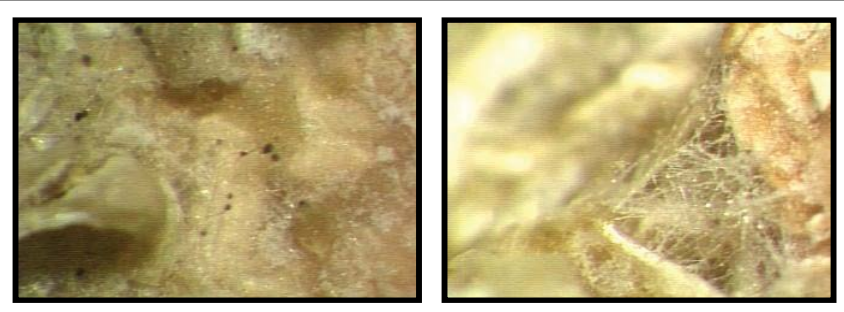

(a) $10 \% \mathrm{w} / \mathrm{w}$ galactose

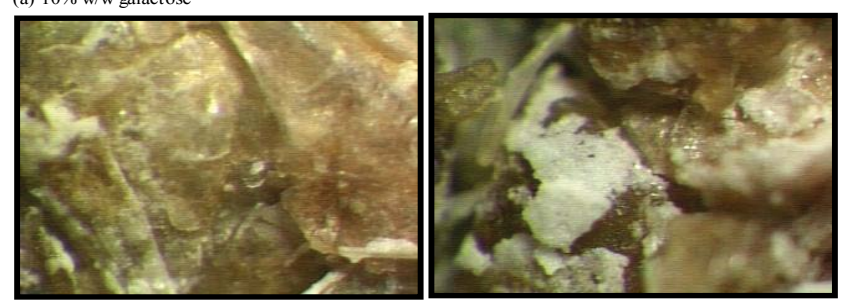

(b) $20 \% \mathrm{w} / \mathrm{w}$ galactose

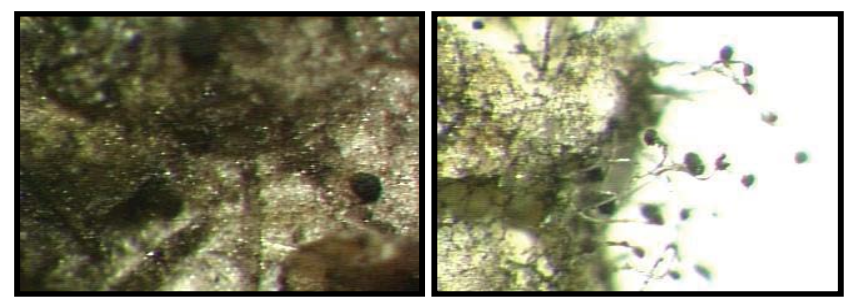

(c) $30 \% \mathrm{w} / \mathrm{w}$ galactose

Figure 15: Visual images (60X) of the shrimp shells after $144 \mathrm{~h}$ of deproteinization as affected by the initial galactose concentrations.

in case of initial galactose concentration $20 \% \mathrm{w} / \mathrm{w}$ and were believed to be the substances that were broken down from the shell matrix during the deproteinization process. For the rune with $30 \%$ initial galactose concentration, the white precipitants were not noticed on the spent shrimp shells and the shells were covered with a large amount of spores.

\section{Conclusions}

Fish proteins are complex molecules consisting of chains of amino acids linked together by peptide bonds. Proteases are proteins structured in such a way that allow them to act as catalysts in the breakage of peptide bonds through a process called hydrolysis as described by the following equation:

Fish protein $\rightarrow$ Polypeptides + Peptides + Amino acids
The degree to which the microorganism hydrolyzes the protein depends on its capacity to produce proteases and the stability of the protease which are affected by the reaction conditions. Thus, a proper amount of balanced nutrients is required to meet the organism metabolic demand for optimum growth and proteases production. In this study, the protein and minerals in the shrimp shells were sufficient for the deprotization to proceed and an external carbon source (galactose) was added. However, the initial galactose concentration affected the different parameters of the deproteinization process (temperature, $\mathrm{pH}$, moisture content, galactose utilization, carbon dioxide evolution, protease activity, residual protein concentration and chitin concentration). The galactose concentration of $20 \% \mathrm{w} / \mathrm{w}$ was found to be optimum whereas that of $10 \% \mathrm{w} / \mathrm{w}$ did not support enough microbial growth and that of $30 \% \mathrm{w} / \mathrm{w}$ inhibited the growth of $A$. niger as was evident from the temperature and carbon dioxide evolution results.

The temperature of the shrimp shells decreased in the first 12 hours (lag) because of the heat losses caused by the evaporation of water (latent heat) and the cooling effect of the inlet air were higher than the heat generation by microorganisms. It then increased durimg the exponential growth phase as a result of heat accumulation in the bioreactor reaching maximum values of $28.9-38.3^{\circ} \mathrm{C}$. The temperature of the exhaust gas also increased due to heat losses from shrimp shells by convection with exhaust gas and water vapor. It reached maximum values of $24.9-29^{\circ} \mathrm{C}$.

The net moisture content of the shrimp shell bed is the initial moisture content plus the moisture contribution of metabolic activity minus the moisture lost by evaporation with the exhaust gas. Although the inlet air was humidified a significant reduction in the moisture content (from 60\% to $25.20-43.71 \%$ ) was noticed by the end of the deproteinization process. The decrease in the moisture content indicated that moisture lost through evaporation exceeded the metabolic water production. The low moisture content may have affected the growth of fungus and protease production and activity. Therefore, in order to maintain the moisture content in the bioreactor at the desired level, the exhaust gas should be passed through a condensation tower and the recovered water pumped back into the bioreactor through the aeration tube.

The $\mathrm{pH}$ of the shrimp shells decreased with time up to a certain value (5.92-6.63) and then increased again to $6.28-8.32$ by the end of the deproteinization process. The decrease in the $\mathrm{pH}$ of the shrimp shells was due to acid protease production while the increase in the $\mathrm{pH}$ of the shrimp shells was due to the buffering capacity of the calcium carbonate released from the shrimp shells.

Temperature rise and carbon dioxide evolution are good indicators of microbial activity in solid state fermentation. The results obtained from the current study showed that the profiles of carbon dioxide evolution were similar to the temperature profiles for all initial galactose concentrations. A strong correlation exists between the concentrations of carbon dioxide in the exhaust gas and the temperature of the shrimp shells.

The protease activity increased with time from an initial value of 0.71 unit/gram (dry weight) reaching 1.77-1.85 units after $144 \mathrm{~h}$ whereas the protein concentration in the shrimp shells decreased with time from $30.84 \%$ to $20.77-25.30 \%$ as a result of protein break down by the proteolytic enzymes produced by $A$. niger. However, the increase in protease activity did not correspond to protein reduction. The highest protease activities (1.85 units) and protein removal efficiency (33.33\%) were achieved with initial galactose concentration of $20 \% \mathrm{w} / \mathrm{w}$ achieve. The low deproteinization efficiency observed in this study could be 
due to: (a) the large particle size of the shrimp shells, (b) the possible protein denaturation as a result of autoclaving of shrimp shells and (c) the high $\mathrm{pH}$ of the shrimp shells which might have interfered with protease synthesis and activity.

The chitin concentration in the shrimp shells increased from $16.59 \%$ to $20.42-21.99$ as a result of protein removal. The highest chitin concentration (21.99\%) was achieved with initial galactose concentration of $20 \% \mathrm{w} / \mathrm{w}$ achieve. The spent shrimp shells obtained from the runs that received galactose concentration of 10 and $20 \% \mathrm{w} / \mathrm{w}$ had a pale pink-orange color which was an indication of the presence of pigments that were not utilized during the fermentation process. The spent shrimp shells obtained from the run that received the galactose concentration of $30 \% \mathrm{w} / \mathrm{w}$ had a gray-black color due to the presence of $A$. niger spores. The high initial galactose concentration $(30 \% \mathrm{w} / \mathrm{w})$ inhibited the growth of $A$. niger and enhanced sporulation.

\section{Acknowledgment}

The research was funded by the National science and Engineering Council (NSERC) of Canada. The support of Dalhousie University and Cairo University is highly appreciated.

\section{References}

1. Hall GM, Reid C, and Zakaria Z (1994) Fermentation of prawn waste by lactic acid bacteria. In: KarnickiZS, Wojtasz-Pajak A, Brzeski MM, and Bykowski PJ (eds.) Chitin World.Sea Fisheries Institute Gdynia, Poland. Proceeding from the $6^{\text {th }}$ International Conference on Chitin and Chitosan, Wirtschaftsverlag, NW.

2. Zakaria Z, Hall G, Shama G(1998) Lactic acid fermentation of scampi waste in a rotating horizontal bioreactor for chitin recovery. Process Biochemistry 33: 1-6.

3. Bustos RO, Healy MG(1994) Microbial deproteinisation of waste prawn shell Institution of Chemical Engineers Symposium Series, Institution of Chemical Engineers, Rugby, England, pp. 13-15

4. Teng WL, Khor E, Tan TK, Lim LY, Tan SC (2001) Concurrent production of chitin from shrimp shells and fungi. Carbohydr Res 332: 305-316.

5. Berka, RM, Dunn-Coleman N, Ward M(1992) Industrial enzymes from Aspergillus species. In: Bennett JW, Klich MA (eds.) Aspergillus Biology and Industrial Applications.Butterworth-Heinemann, Stoneham MA.

6. Wang LS,ChioH S(1998) Deproteinization of shrimp and crab shell with the protease of Pseudomonas aeruginosa K-187. Enzyme and Microbial Technology 22(7): 629-633.

7. Pandey $A(1992)$ Recent process developments in solid-state fermentation Process Biochemistry 27: 109-117.

8. Naidu, Panda $\mathrm{G}(2003)$ Studies on $\mathrm{pH}$ and thermal deactivation of pectolytic enzymes from Aspergillus niger. Biochemical Engineering Journal 16(1): 57-67.

9. Wehr MH, Frank J(2004) Standard Methods for the Examination of Dairy Products (17thedn.) American Public Health Association, Washington, DC.

10. Hansen H, Aschan $M(2000)$ Growth size- and age-at-maturity of shrimp Pandalus Borealis, at Svalbard related to environmental parameters. Journal of Northwest Atlantic Fishery Science 27: 83-91.

11. Chow PS, Landhäusser SM (2004) A method for routine measurements of tota sugar and starch content in woody plant tissues. Tree Physiol 24: 1129-1136.

12. Zakaria Z, Hall G, Shama G(1997) Lactic acid purification of chitin from prawn waste using a horizontal rotating bioreactor. Unpublished $\mathrm{PhD}$ thesis, Loughborough University. Loughborough, UK.

13. Ghildyal NP, Ramakrishna M, Lonsane B, Karanth N,Krishnaiah MM et al (1993) Temperature variations and amyloglucosidase levels at different bed depths in a solid state fermentation system. The Chemical Engineering Journal 51(2): B17-B23.

14. Gowthaman MK, Raghava Rao KS, Ghildyal NP, Karanth NG (1993) Gas concentration and temperature gradients in a packed bed solid-state fermentor. Biotechnol Adv 11: 611-620.

15. Pandey $A(1990)$ Production of glucoamylase enzyme in solid-state fermentation. International Symposium on Industrial Biotechnology, Hyderabad, India, pp. 18-20.
16. Ghildyal NP Gowthaman M, Raghava Rao K, Karanth N, et al.(1994). Interaction of transport resistances with biochemical reaction in packed-bed solid-state fermentors: effect of temperature gradients. Enzyme and Microbial Technology 16(3): 253-257

17. Pandey $A(2003)$ Solid-state fermentation. Biochemical Engineering Journal 13(2-3): 81-84

18. Rathbun BL, Shuler ML (1983) Heat and mass transfer effects in static solidsubstrate fermentations: design of fermentation chambers. Biotechnol Bioeng 25: 929-938.

19. Saucedo-Castañeda G, Gutiérrez-Rojas M, Bacquet G, Raimbault $M$ Viniegra-González $\mathrm{G}$ et al. (1990) Heat transfer simulation in solid substrate fermentation. Biotechnol Bioeng 35: 802-808.

20. Ben-Hassan R, Ghaly A, Ben-Abdallah N(1993) Heat generation during batch and continuous production of single cell protein from cheese whey. Biomass and Bioenergy 4(3): 213-225.

21. Ghaly A, Kamal M, Avery A(2003) Influence of temperature rise on kineticparameters during propagation of Kluyveromyces fragilis in cheese whey under ambient condition. World Journal of Microbiology 19: 741-749.

22. Ghaly AE, Kok R, Ingrahm JM (1989) Growth rate determination of heterogeneous microbial population in swine manure. Appl Biochem Biotechnol 22: 59-78.

23. Esfahani Z, Shojaosadati S, RinzemaA(2004) Modelling of simaltenous effect of moisture and temperature on $A$. niger growth in solid-state fermentation. Biochemical Engineering Journal 21: 265-272.

24. Pedersen H, Beyer M, Nielsen J (2000) Glucoamylase production in batch, chemostat and fed-batch cultivations by an industrial strain of Aspergillusniger. ApplMicrobiolBiotechnol 53: 272-277.

25. Szewczyk K, Myszka L(1994)The effect of temperature on the growth of $A$ niger in solid state fermentation. Bioprocess Engineering 10: 123-126.

26. Yang SS, Chiu WF (1986) Protease production with sweet potato residue by solid state fermentation. Zhonghua Min Guo Wei Sheng Wu JiMian Y XueZaZhi 19: 276-288.

27. Beaney P, Mendoza J, Healy M(2005) Comparison of chitins produced by chemical and bioprocessing methods. Journal of Chemical Technology and Biotechnology80: 145-150.

28. Yang SS, Ling MY (1989) Tetracycline production with sweet potato residue by solid state fermentation. BiotechnolBioeng 33: 1021-1028.

29. Yang SS (1988) Protein enrichment of sweet potato residue with amylolytic yeasts by solid-state fermentation. BiotechnolBioeng 32: 886-890.

30. Villegas E, Aubague S, Alcantara L, Auria R, Revah S (1993) Solid state fermentation: acid protease production in controlled $\mathrm{CO} 2$ and $\mathrm{O} 2$ environments BiotechnolAdv 11: 387-397.

31. AndradeVS LA, Sarubbo, Fukushima K, Miyaji M, Nishimura K, Takaki G,et al. (2002) Production of extracellular proteases by Mucor circinelloides using D-Glucose as carbon source/substrate. Brazilian Journal of Microbiology 33: 106-110.

32. Diaz LF, Savage, Eggerth G, Golueke, et al.(1993) Composting and Recycling of Municipal Solid Waste. Lewis Publishers, Boca Raton, FL.

33. Ikram-Ul-Haq, Ali S, Qadeer MA, Iqbal J (2005) Optimization of nitrogen for enhanced citric acid productivity by a 2-deoxy D-glucose resistant culture of Aspergillusniger NGd-280. BioresourTechnol 96: 645-648.

34. Lonsane BK, Ghildyal N, Budiatman S, Ramakrishna S(1985) Engineering aspects of solid state fermentation. Enzyme and Microbial Technology 7: 258-265.

35. Bellon-Maurel V, OrliacO, Christen P(2003) Sensors and measurements in solid state fermentation: a review. Process Biochemistry 38: 881-896.

36. Ashour SA, el-Shora HM, Metwally M, Habib SA (1996) Fungal fermentation of whey incorporated with certain supplements for the production of proteases. Microbios 86: 59-69.

37. Ray MK, Devi KU, Kumar GS, Shivaji S (1992) Extracellular protease from the antarctic yeast Candida humicola. Appl Environ Microbiol 58: 1918-1923.

38. Bulthuis B, Rommens C, Koningstein G, StouthamerA, van Verseveld H, et al (1991) Formation of fermentation products and extracellular protease during anaerobic growth of Bacillus licheniformis in chemostat and batch-culture. Antonie Van Leeuwenhoek 60 : 355-371.

39. Cira, LA, Huerta S, Hall G, Shirai K(2002) Pilot scale lactic acid fermentation of shrimp wastes for chitin recovery. Process Biochemistry 37: 1359-1366. 